\title{
A Mulher Como Ciência de Vida em Torno da Filosofia do Parto Humanizado
}

\author{
Vicente Paulino ${ }^{1}$ \\ Irta Sequeira Baris de Araújo ${ }^{1}$ \\ ${ }^{1}$ Universidade Nacional Timor Lorosa'e, Timor-Leste; E-Mail: vicentepaulino123@gmail.com; barisaraujo@gmail.com
}

\begin{abstract}
Resumo
Neste artigo pretendemos usar a abordagem da bioética para dar o sentido filosófico ao conceito "sagrado parto" e o "parto sagrado". O "sagrado parto" está associar-se aos elementos corporais de "homem-mulher", mas especificamente para o conjunto de células do corpo da mulher. Enquanto o "parto sagrado" está associar-se ao processo da saída do "corpo novo" no canal da vagina da mulher, e portanto, aqui a vagina assume um papel muito importante na condução da saída do "corpo novo", combinando com outras células sanguíneas para que a viagem do "corpo novo" ao mundo se realiza com sucesso, embora a dor carregada pela mulher parturiente é bastante dolorosa.
\end{abstract}

Palavras-chave: ciência de vida; mulher; parto humanizado; parto sagrado; sagrado parto.

\begin{abstract}
In this article we intend to use the bioethical approach to give the philosophical meaning to the concept of "sacred birth" and "birth sacred". "Sacred birth" is associated with the bodily elements of "man-woman", but specifically for the body cells of the woman. While the "birth sacred" is associated with the process of leaving the "new body" in the vaginal canal of the woman, and therefore, here the vagina plays a very important role in the conduction of the "new body" exit, combining with other Blood cells so that the journey of the "new body" to the world succeeds, although the pain carried by the woman in labor is quite painful.
\end{abstract}

Keywords: life science and humanized birth; sacred birth; sacred childbirth; woman.

\section{Consideração Prévia}

A prá Parto humanizado é uma identidade para os herdeiros do parto sem dor. Este movimento constitui-se em torno de uma ideia "fenomenológica da razão", ou seja, de uma aplicação de conjunto de "saberes", "saber-fazer" e "saber-ser", que vêm no campo da bioética. Para explicar o modo como o parto humanizado surge na história da humanidade, tentamos fazer o uso da linguagem filosófica do termo "sagrado parto" e "parto sagrado" nas práticas parteiras tradicionais e parteiras profissionais. Para tal fenómeno, apresentamos o caso timorense como exemplo concreto para perceber o sentido de vida iniciado no "sagrado parto" e "parto sagrado".

Certo é que pensar a vida no processo da constituição do "corpo novo" no "ventre sagrado" da mulher na atualidade é rever padrões que foram alterados pela ciência medicina moderna de enfermagem, deixando para traz os saberes locais na condução do processo "sagrado parto" e "parto sagrado". É por isso que a incerteza tomou conta, há dúvida de estar fazer o que é certo e conduzindo o uso das máquinas para controlar o processo do parto de uma mulher. Muitos profissionais de saúde estão distantes dos seus conhecimentos naturais, ignorando a convivência "especial de atendimento" chamada "sorriso de trinta cêntimos" aos pacientes. Sabendo que com um "sorriso de trinta cêntimos" aliviar a dor dos pacientes, portanto, a aplicação deste método que cada paciente procura sentir. Aliás, a tarefa de humanizar a vida a partir dos 
conceitos "sagrado parto" e "parto sagrado" é uma missão atual das famílias e dos profissionais de saúde. Trazer esses conceitos para garantir os princípios de humanização da vida em torno da filosofia do parto humanizado. Trata-se de valorizar a vida humana enquanto parte integrante dos valores universais.

Biotecnologia e o acesso aos conhecimentos do parto humanizado tradicionais são temas que estão a ser debatidos pelos profissionais da saúde, académicos investigadores de diversas áreas do saber. Assim, ao mesmo tempo em que se promovia o questionamento sobre a medicação excessiva do parto (representado pelas cesáreas), cresciam as reivindicações dos movimentos feministas e sanitaristas em torno dos direitos sexuais e reprodutivos. Na verdade, tais preocupações não eram propriamente novas, uma vez que, dentro da obstetrícia aplica o novo mecanismo para questionar a forma como o parto é vivenciado e assistido. Aliás, não podendo, ignorar também que da bioética ao biomedicina, segundo a qual as reflexões em torno destas temáticas associam-se sempre ao campo de interdisciplinaridade, ou pluridisciplinaridade, onde a bioética envolve, certamente, vem da biologia e da filosofia e que nelas se encaixam os avanços biomédicos e biotecnológicos. Será por esta razão que surge o termo "parto humanizado"? Parte desta pergunta que iremos abordar filosoficamente a funcionalidade dos saberes locais (mais para a questão de bioética) em cruzamento dos saberes modernos (mais para a biomedicina) no "sagrado parto" e "parto sagrado".

\section{2. 'Sagrado Parto’ e 'Parto Sagrado': Uma Definição Filosófica}

A expressão "sagrado parto" não pode ser explicada por si só, mas, como é fácil de verificar, só adquire sentido filosófico se consideramos o corpo como um objeto vivo e sagrado do ser humano, pois ele é um território sagrado. Não se pode tratar apenas de um monte de órgãos corporais fluidos pela presença física e variadas funções, mas pela sua "essência absoluta". Na língua hebraica, todas as partes do corpo humano são constituídos por elementos psíquicos e espirituais. Neste sentido, importamos dizer que cada parte do corpo humano conduz uma consciência do verdadeiro 'Eu' e de sua unidade para uma construção real de vida. Os sábios gregos antigos consideraram o sujeito do 'eu' como uma pessoa 'única e irrepetível', porque ele é um ícone divino que foi criado a partir do som de um verbo, que na visão cristã, tal ícone divino está no sujeito "trinitário invisível”. Daí somos um falante de um verbo 'unitário' que procede a união de três figuras num só texto de "transfiguração do verbo encarnado". Isto significa que "O corpo humano possui uma estrutura e uma unidade que vão além da própria matéria, realidade essencial da pessoa. É um santuário onde a sabedoria divina se torna visível. [É por isso que] a sabedoria judeo-cristã ajuda a viver o corpo como um templo, em que pesem todos os equívocos castradores e abomináveis que a história ocidental e oriental proferiu (e ainda profere) sobre o corpo" (Miranda, 2000, p. 11).

Os estudos realizados em países ou grupos culturais distintos têm demonstrado que a essência do corpo do ser humano é uma parte da 'alma pré-constituída', desde as pequenas células dentro do próprio corpo e até a acção inalienável da humanização do ser no 'ventre sagrado' de uma mulher. É por isso que a humanização do parto é sempre associada à essência do próprio corpo, que a mulher tem em si o 'fluxo de vida', embora nem sempre considerada como uma 'figura especial' nos certos grupos diferenciados.

Eticamente, escreve Irta Sequeira Baris de Araújo (2013, p. 56):

se nós consideramos o corpo das mulheres no parto, corresponde a um processo de nascimento do "novo corpo" como objeto sagrado, daí o "novo corpo" que vem no "sagrado parto" passa então a poder ser considerado como resultado do ato de uma instância determinada que se dá conta a "significância do corpo". Para este fato, podemos dizer que a essência do corpo não está apenas na pura subjetividade (está sujeito, portanto a todas as marcas históricas, culturais, sociais, que são impressas nele), mas está também na produção biológica. A este último, devemos dizer que é um recetáculo recheado de inscrições simbólicas adquiridas pelo sujeito na sua relação como outro, relação está constituída através da linguagem, isto é, a carne, ossos e todo organismo que são afetados pelo significante da linguagem, transforma-se em corpo.

Neste contexto, contínua a autora que a terminologia do 'sagrado parto' e do 'parto sagrado' é também um signo que estabelece o diálogo cognitivo associado a vida do ser humano em que a relação dual 'homem-mulher' torna-se cada vez mais ativa no momento decisivo da realização do ato pré-constituído de uma vida através do "sagrado parto" e que depois acolhe o "novo corpo" a partir da ação do próprio "parto sagrado". 


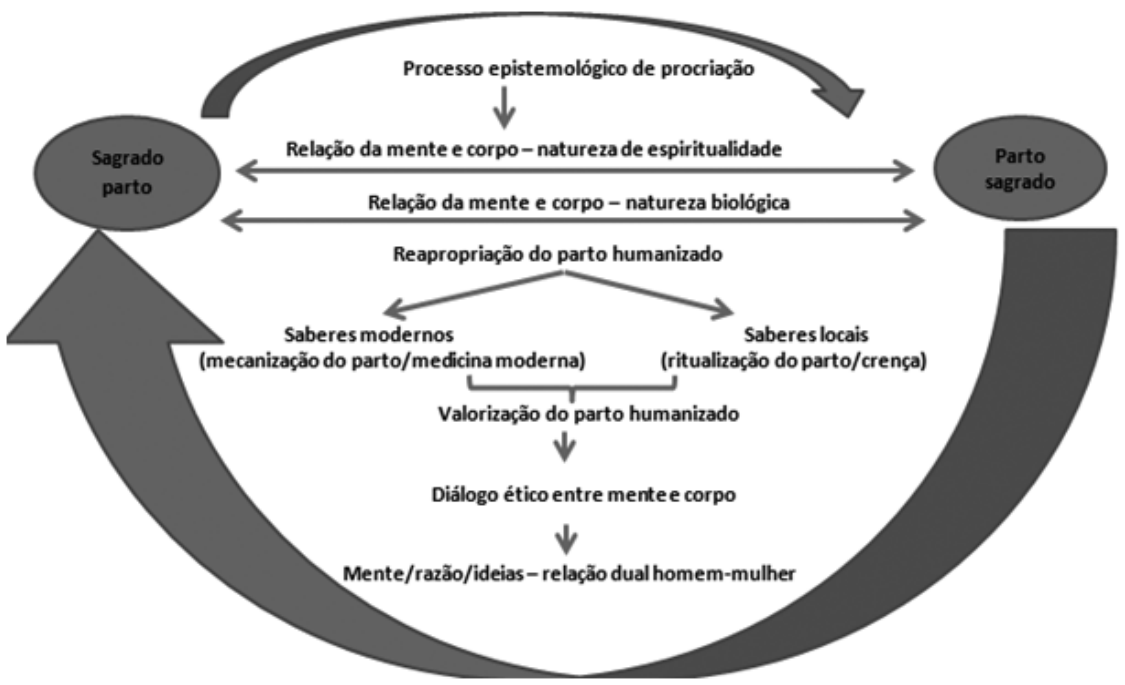

Figura 1. Uma conceção filosófica do 'sagrado parto' e 'parto sagrado'

Este esquema dá razão a interface e a fusão entre o "sagrado parto" (mundo interior da mulher, refere-se exatamente todo o elemento que possibilita a formação do "corpo novo" no ventre da mulher) e o "parto sagrado" (mundo exterior da mulher, refere-se o processo de saída do "corpo novo" no "sagrado ventre" da mulher). Ou seja, a fusão entre o mundo interior extrafamiliar da mulher (é o próprio ventre e toda a célula corporal que o rodeia) e a ponte de passagem em busca a luz do mundo oferecida pelo canal da vagina da mulher com todo o amor, embora arrisca-se a vida para fazer nascer outra vida de sua própria carne. Isso é que se chama “processo epistemológico de procriação" e, por tal razão, precisamos mesmo na vida casal ter uma relação dialógica na valorização dos princípios básicos do "parto humanizado".

É necessário usar a abordagem da bioética para dar o sentido filosófico ao conceito "sagrado parto" e o "parto sagrado". O "sagrado parto" está associar-se aos elementos corporais de "homem-mulher", mas especificamente para o conjunto de células do corpo da mulher. É certo que o 'sagrado parto' mais para o território sagrado da mulher que é o próprio "sagrado ventre", pois neste espaço que constitui o 'novo corpo' de um ser. Sabendo que o "sagrado ventre" é constituído por diversos elementos essenciais que vai assegurar o processo de 'pré-constituição do novo corpo'. Enquanto o "parto sagrado" está associar-se ao processo da saída do "corpo novo" no canal da vagina da mulher, e portanto, aqui a vagina assume um papel muito importante na condução da saída do "corpo novo", combinando com outras células sanguinas para que a viagem do "corpo novo" ao mundo se realiza com sucesso, embora a dor carregada pela mulher parturiente é bastante dolorosa. A este facto, consideramos a mulher como "autora primária" ou luz da ciência de vida no mundo humanizado.

Nesse sentido, dizia Irta Sequeira Baris de Araújo (2013, pp.60-61) que nós devemos considerar a mulher como "fetomaromak - grande mãe ou literalmente traduzida como deus-mulher", e por isso, o patriarcado procura sempre a afirmar e defender os cultos da "Grande-Mãe", interditando os seus rituais, "ami lakohi tula liman ba imi, imi feto ne'e feto maromak, husi imi mak ami moris - vós sois mulheres deus, vós sois a nossa vida, não queremos magoar-vos" e elevando seus símbolos e valores ${ }^{1}$. Entretanto, a relação igualitária "mane-feto" foi reforçada, isto é, a mulher declarada como um ser superior, abençoada e cheia de alma. Por isso mesmo que a relação dual "mane-feto", especificamente a dimensão feminina da divindade na consciência coletiva, está sendo fortalecido o "sagrado parto" onde nasce um "novo corpo", daí se encontra a verdadeira "sagrada consciência" no corpo recém-nascido e a revalorização do valor "sagrado feminino".

Voltando ao sentido "mane-feto" na conceção "feto-maromak", o centro de acolhimento do conceito "sagrado parto" e "parto sagrado", que de algum modo, Luís Cardoso na sua obra Crónica de Uma Travessia (1997) considera "feto Timor" (mulher Timor) como "feto maromak" (mulher deus), pois uma personagem que ocupa a posição de "Mãe-Terra", no aspeto religioso, é mais forte do que a relação de "fetosá-umane" ${ }^{2}$.

\footnotetext{
${ }^{1}$ Sendo assim, a realidade nos mostra que muitos homens batem nas suas mulheres, tratando-as desumanamente, pois o que lhes interesse é o apetite sexual em produzir filhos, sem dar nenhuma atenção à saúde de sua mulher.

${ }^{2}$ Fetosá significa tomador da esposa e umane significa doador de esposa. Esse sentido de "tomar" e "doar" se estabelece entre duas famílias mediante o casamento. Trata-se de relação que se estabelece entre si numa série de obrigações e na dialética de interdependência que se norteiam em toda a vida familiar, social e ritual dos timorenses.
}

Revista Internacional em Língua Portuguesa, 2018, №34, Ciências da Saúde e Tecnologia, pp. 37-52 


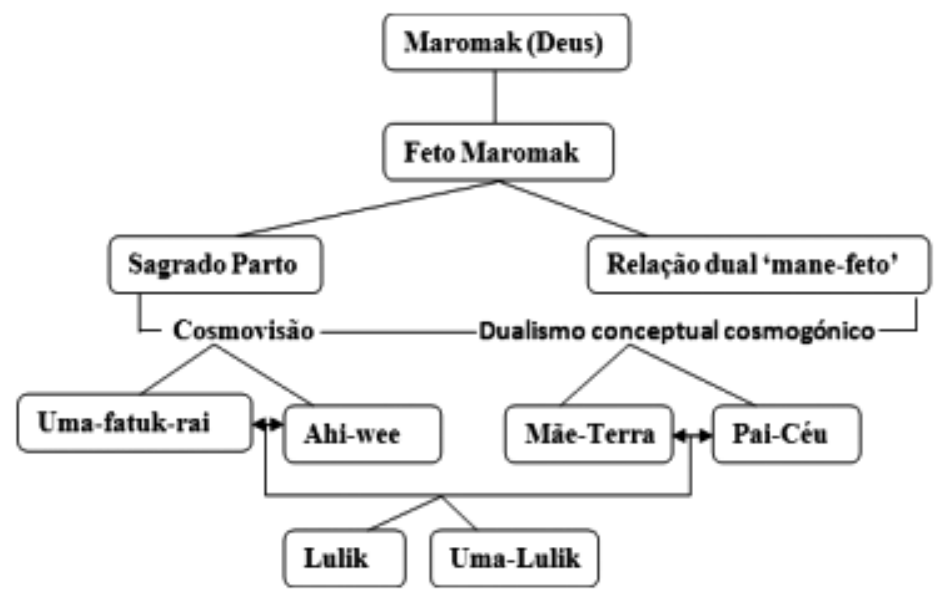

Figura 2. Feto Maromak em torno da cosmovisão e dualismo conceptual cosmogónico (Araújo, 2013, p. 59).

Parte-se neste "esquema dualitório" de Irta Sequeira Baris de Araújo, compreendemos que a aplicação do termo "feto maromak" às mulheres timorenses tem a ver com o "sentido de governabilidade" do poder feminino mediante ao poder masculino. Em certas culturas, a mulher é herdeira de continuidade da linhagem e dos bens materiais. É por isso, nas culturas matrilineares consideram as mulheres como "rainha" e responsável pela manutenção de sua origem e das lições de vida transmitidas pelos seus antepassados e da Casa Sagrada em que elas próprias fazem parte (Paulino \& Gomes, 2017).

Sintetizando que, de forma geral, a relação dual "homem-mulher" pode ser explicitada de seguinte maneira - como salienta Maria Manuela Ferreira Garcês (2011) - o momento do parto é um momento marcante na vida de um casal, sendo necessário o apoio tanto da mãe como do pai. Neste contexto, podemos dizer que o parto é uma micro-transição na qual o homem literalmente se torna num pai, dentro de uma macro-transição (Draper, 2003), isto significa que a figura sente-se confiante com o papel de apoio à mulher, ao perceber que se torna uma figura importante no apoio psicológico à sua companheira (Storti, 2004), entretanto, ser um pai ou uma mãe, suficientemente bons, é construído previamente ao ato de se tornarem pais, por pressupostos culturais partilhados, em particular sobre o que se espera de um "bom pai" ou de uma “boa mãe" (Woodward, 2000).

\section{Dialética da Consciência Ética de Interpretação do 'Sagrado Parto' e 'Parto Sagrado'}

Temos de compreender a dialética da consciência ética de interpretação do "sagrado parto" e "parto sagrado" a partir de "humanização do sentido de vida", pois, num mundo em que vivemos está plena mudança e por isso precisamos entender e descobrir o sentido da nossa vida no quadro epistemológico da "arte de viver". Temos que valorizamos necessariamente também a humanização da nossa vida com a fundamentação da razão iluminada pela ritualização da fé que capaz alargar o horizonte do "diálogo da mente" e do "diálogo do corpo" para enfrentar os grandes desafios da vida na formação do "corpo novo".

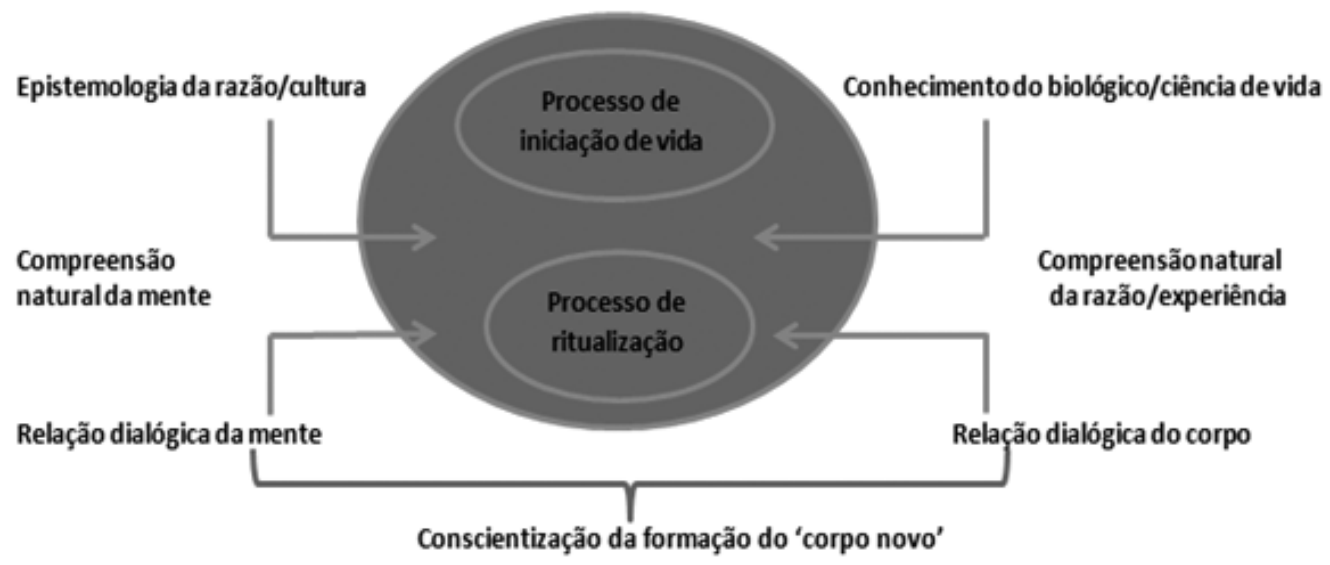

Figura 3. Epistemologia de argumentação relativamente a formação do 'corpo novo' 
Trata-se de um esquema que possibilita o diálogo entre o que a sociedade aponta como resultado da conscientização da formação do "corpo novo". Com isso, cria-se o sentido "epistémico da razão" e o sentido "epistémico biológico" na formação do "corpo novo" dentro do "sagrado ventre" da mulher, em que se complementam o modo como conduzem a sua constituição a partir do encontro entre o esperma (do homem) e o óvulo (da mulher) no interior da vagina da mulher. Certo é que isso funciona com a mútua aceitação por parte da mente e do corpo (tanto do homem bem como da mulher).

Se no caso, porventura, numa relação biológica estabelecida entre homem e mulher na comunicação espiritual da mente e do corpo, não dá resultado positivo, nós não podemos dar a culpa diretamente ao nosso corpo e a nossa mente, mas precisamente reconhecer que na natureza da vida humana encontra-se, pelo menos, alguns casais que não conseguem ter filhos no processo de estabelecimento da "relação biológica" devido a "intervensaun mai husi nakukun sira adat nian intervenção do lado escuro da própria cultura, por exemplo, inan nian folin aman seidauk fó - o dote (barlaque) da mãe ainda não foi entregue pelo pai" e devido o distúrbio psicológico corporal e da mente desses mesmos casais. Sendo assim, cada ser humano (tanto homem bem como mulher) deve reconhecer essa lei de vida, pois o que mais importante aqui é valorizar o sentido de complementaridade como "companheira" e "companheiro" em todo o percurso de vida, contrariando a conceção daqueles que pensam em "produzir", mas não responsabilizam³. E isso, não é "humanizar a vida", mas desumanizar a vida daquele que veio ao mundo e incluindo aquela que o acolhe no seu "sagrado ventre" durante nove meses.

Neste momento que a nossa sociedade vive, na convergência e divergência de tantos propósitos, motiva a nós enquanto humano a refletirmos sobre a ideia filosófica em torno do parto humanizado como uma forma de diálogo homem-mulher a respeito da formação de um "corpo novo" dentro do ventre da mulher. Devemos, sem dúvida, reconhecer que a formação de um "corpo novo" começa a estabelecer com o diálogo entre a mente e o corpo do homem-mulher. É mais fortemente na relação dialógica da mente e do corpo da mulher que acolhe o "corpo novo" no seu "sagrado ventre".

Temos certeza de que a relação recíproca de uma mulher com o seu "sagrado ventre" vai continuar a humanizar o sentido da vida. Aliás, o "sagrado ventre" é a primeira casa dos seres humanos antes de virem ao mundo dos homens propriamente dito. Precisamente, por isso, que temos de considerar a mulher como uma "relíquia de vida", pois ela é parceira inalienável na vida dos homens. Assim, a mulher é pedra basilar mais preciosa da humanidade, pois ela é constituída pela sua própria vida que é o seu próprio "sagrado ventre", ou seja, a mulher é uma parte daquilo que há-de existir dentro dela, porque só dentro de sua vida que faz existir a nova vida e, portanto, para ela a vida é todo o seu ser. É portanto, a partir daquilo que existe dentro dela pressupõe um contacto espontâneo e duradouro com o seu próprio mundo interior, que é fonte de vida alimentada pelo seu "sagrado ventre". Isso a dispõe a acolher e compreender como "sagrado parto", onde o processo de iniciação da nova vida se estabelece. Sendo assim, no processo de conscientização da formação do "corpo novo", existe uma complementaridade relacional entre homem e mulher, ou seja, podemos dizer que enquanto o homem tende a dominar a realidade exterior e a matéria da produção biológica (materialização do corpo no enquadramento de "toca tocando), a mulher é levada a cuidar dos valores de vida (espiritualização do corpo e da mente).

\footnotetext{
${ }^{3}$ Pela dimensão da ética, o sentido de "pensar só em produzir", mas "não responsabilizam" é, em seu conjunto, um sistema de dominação cultural de desejo e gozo pessoal de um "homem fugitivo" nos problemas que o rodeiam. É necessário referir ainda outros sistemas de dominação, como o egoísmo pessoal, a estrutura de classes sociais ou a posição no cargo de trabalho, e estes dominam a cultura do desejo - o gozo prazer. Digamos que o patriarca liberta o seu desejo com a missão de "pensar em produzir", de seguida, foge na responsabilidade, deixando a mulher aborrecida com "ventre enchido por um corpo novo e vivo"; entretanto, o patriarca pensa no sexo e depois definindo-o nos termos "prazeres corporais" do género desmoralizado. Certo é que, neste caso, o patriarcado constrói o desejo-prazer ambicioso e constrói a psique de egoísmo e de arrogância, através de duas divisões de pensar em "querer ter carne fresca". A primeira, a divisão de pensar é voltada ao sentido mais emocional que se reflete para a "paixão - apaixonado por você", mais tarde acontece o fluido-prazer de "dois corpos toca tocando" e alguns meses depois acontece uma "gravidez indesejada" - o patriarca não assume o ato e foge da responsabilidade; a mulher fica com a dor da mente a cuidar o "anjinho vivo no seu ventre" até ao seu nascimento. É portanto, o ato imoral do patriarcado é fluído pela experiência de "individualização" e de "egoísmo" e a sua "ligação" com o mundo dos prazeres é mais forte do que "assumir a responsabilidade" mediante do ato cometido. Enquanto a mulher assume com toda a responsabilidade e todo o amor e a sua ligação com a vida é mais forte do que os prazeres mundanos.
} 


\section{1. 'Sagrado Sarto' como Processo de Iniciação da Nova Vida Jugular}

Pela dimensão espiritual, o sucesso pessoal de uma mulher na condução do processo do "sagrado parto" é um orgulho tão heroico, pois está pronto a oferecer o seu "sagrado ventre" para acolher o "corpo novo" que há-de nascer como "pedaço de sua carne" e, ao mesmo tempo, como "pedaço de um tempo que há-de-vir", como aclamava os versos do poema de Vicente Paulino, intitulado "tempo que há-de-vir" :

\section{Tempo há-de-vir}

Não conheço o tempo da minha vinda, pela manhã ou pela tarde.

Só sei que há um regulador dentro de mim, não sei qual é? Mas há dentro de mim.

Carne do meu corpo, pedaço do tempo.

Ar do meu peito, regulador da passagem.

Caminhos com fim da manhã ou da tarde, só o tempo que pronúncia.

Sou futuro de um tempo que há-de-vir. Mas quando? Será amanhã? Ou depois?

Sei lá, deixa o vento passa.

Há-de-vir brilho da madrugada.

Ah!!! agora já sei que quem sou.

Sou um pedaço do tempo que há-de-vir.

Trata-se de um poema que pode ter várias interpretações, dependendo a maneira de cada um vê a realidade em sua volta. É na verdade que trazemos o poema aludido na abordagem do conceito "sagrado parto" enquanto forma de iniciação da nova vida é muito percetível e combinável, porque reflete a validade da nossa viagem em "nada existia", mas começa a existir com o cruzamento de "sangues brancos" no território feminino predeterminado pela infinita "natureza criadora", produzindo efeito e a mulher pela sua prontidão acolhe o "corpo novo" no seu "sagrado ventre" até a sua saída no tempo que há-de-vir. Além disso, após a saída do "corpo novo" no "sagrado ventre" da mulher, esse corpo novo recém-nascido vai crescer e viver na sociedade, daí começa a reconhecer que o seu corpo é "um pedaço do tempo que há-de-vir" e contínua a ser "há-de-vir".

Em virtude deste, as representações do corpo das mulheres timorenses na saúde, como exemplo concreto, no que diz respeito à cultura da maternidade na uma-lulik (casa sagrada) que apresentam diferentes ordens de realidade. Isto é, segundo o nosso conhecimento, o corpo feminino timorense é fragmentado em diferentes olhares, que configuram os campos biológico, psíquico e social. Na abordagem contemporânea do corpo destaca-se a supremacia da ordem moral e biológica, que conformou a constituição da cultura moderna do "parto" que, no caso concreto de Timor-Leste, o "sagrado parto" na cultura das parteiras encontra-se ainda numa fase de configuração do campo de saúde, inclusive a prestação dos serviços do parto enquanto parte integrante do processo de iniciação da nova vida (cf. Araújo, 2013, pp. 55-56).

O corpo na sociedade timorense é compreendido mediante o conceito da ideia do "fluxo de vida" e "ciclo de vida", que se impregnou na cosmovisão da racionalidade de "ser sagrado" desde o seu nascimento. Isto leva-nos pensar, evidentemente, que vale a pena "fazer sentido de ter corpo", ou seja, "o meu corpo faz sentido". É certo que "fazer sentido" é uma expressão que se presta a alguma interconexão do nosso corpo-a-corpo com as coisas "fazem-se sentido" (Bártolo, 2007, p. 47) na cultura timorense, por exemplo, quando um homem e uma mulher se unem pelo sagrado ritual matrimónio proferido pelo lia-na'in ${ }^{5}$,

Iha loron hirac ne'e, iha uain hirac ne'e, ami rohan rua, ami sudin rua,

${ }^{4}$ Este poema é um dos poemas que professor Vicente Paulino escreveu e constatado no seu livro "Poemas - coisas reflectidas". Aliás, é um dos poemas que já foi lido ou aclamado pela Ana Isabel da Silva (aluna do 30 ano do Departamento de Língua Portuguesa) em 5 de Maio de 2017 na semana de Língua Portuguesa promovida pela UNTL.

${ }^{5}$ É a mesma situação que se aplica no ritual matrimónio dos cristãos. Ver Jorge Barros (1964), "Barlaque”, in Seara - Boletim eclesiástico da diocese de Díli, ano 16, no3 e 4, Timor-Díli. 
souru mútu málu, halibur hamútuc,

hôdi hassa'e ona êmi rua,

hôdi hatur ona êmi rua

ba fafata rohan,

ba ai lain tutun.

(...)

Halo emi rua ici ida ona,

halo emi rua lolo ida ona,

(...)

Ami atu hanourin hela,

emi rua feto no ná,

emi rua atu tau lerec ba emi fuc lahan,

emi rua atu sicat lerec ba emi noce dalas,

La'a hodi hanoin nafatin;

tur hodi hanoin beibeic;

ami feric, ami catuas,

ami ibun hanourin ida ne'e,

ami lian cababan ida ne'e:

oras ne'e emi rua ici ida ona,

emi rua lolo ida ona;

saran ona óe, saran ona táli,

ba emi rua liman,

atu hodi ucun malu,

atu hodi hanourin malu. (...)

Nestes dias, durante este tempo,

nós das duas partes, dos dois lados,

nos reunimos,

para vos colocar a ambos,

para vos implantar a ambos

nas extremidades da viga,

no cimo da árvore.

(...)

Tornando-vos um só corpo,

fazendo-vos uma pessoa.

(...)

Dar vos um conselho,

a vós, irmã e irmão,

para que o escondais no cabelo,

o guardeis nas pregas do 'tais',

para que, andando, sempre penseis;

sentados, sempre vos lembrais;

que nós velhas e velhos,

vos ensinámos isto,

vos aconselhámos isto:

sois já um só corpo,

sois já um só,

depusemos-vos já a rota e a corda,

nas mãos de vós ambos,

para vos governardes,

para vos conduzirdes um ao outro. (...)

No final do ritual, os lia-na'in chamam os recém-casados e dizendo:

Emi rua simu ba malus tahan ne'e 
Emi rua hola ba bua balun ne'e cnuhas no is atu tun ba imi icin [isin] tun ba imi lolon

Recebei ambos estas folhas de bétel

Tomai estes bocados de areca

Para que o hálito e o sopro vos penetrem

vos entrem no corpo.

Julgamos ser importante sublinhar a existência da validade do casamento pelo "ritual matrimónio" e, pelo facto de, o processo tem sido realizado na presença dos anciãos. Isso deve ver-se no contexto de, a noiva se levantar do seu lugar da "lareira" e ir sentar-se ao lado do noivo, cada um mascando uma folha de bétel e um dos dois bocados de areca insuflados pelos velhos e colocados no há-matan. É culturalmente, na sociedade timorense, o começo da nova era de serem independentes e autónomas, de se sentirem chamados a fazerem coisas importantes na vida familiar e social.

\section{2 'Sagrado Parto' e 'Parto Sagrado' como Processo de Ritualização}

Sabemos que a nossa sociedade é, cada vez mais, imbuído pelo trabalho das máquinas, pois, o desenvolvimento da ciência e da técnica tem levado a uma exploração de "mecanização de vida" cada vez maior no mundo de medicina moderna, deixando cada vez mais na sombra os fatores e os valores subjetivos e espirituais. Essa mentalidade mecanista tende a conquistar a verdade objetiva verificável e controlável e, se desenvolve com fundamento na pura racionalidade, por isso que quando surge um pequeno problema no processo de realização do "parto sagrado", resolve-se logo com o conceito de “opera deit ona - só operar, fazer operação cesariana" ou "tenke opera duni, se lai... - tem que operar, se não ... ${ }^{\prime \prime}$. Esse processo corresponde à mentalidade e às tendências próprias daqueles que baseiam-se puramente na "mecanização da medicina moderna" com maior ou menor experiência, sem fazerem esforços para saber - na cultura timorense, ou ainda existe na cultura de outros povos asiáticos, africanos, brasileiros e alguns ocidentais (a estes últimos não tão visível, mas aplica-se ainda certos rituais relacionados com o problema encontrado na realização do "sagrado parto") -, "karik, iha fukun ruma husi uma-lulik laran - problemas alheios dentro da casa sagrada" ou "inan nia folin, aman seidauk entrega hotu - o

${ }^{6}$ Do ponto de vista ético, os médicos e enfermeiros têm obrigação moral de fazer junção de dois saberes: saberes de medicina moderna e saberes locais (tradicionais) no tratamento de seus pacientes. Não pode ignorar os saberes locais na aplicação da medicina moderna forçada pela técnica de computação, olhando apenas a pulsações das máquinas sinalizadas pelo som tic-tac-tic. Além disso, ainda no caso do "parto sagrado", se um bebé nasce com alguns problemas físicos, nomeadamente "doença interior" pré-estabelecido dentro do corpo do bebé - exatamente na barriga; depois o bebé de ter saído no ventre de sua mãe através de uma operação cesariana, o bebé é levado diretamente para uma análise clínica e que no fim, o médico especialista em pediatra tomou uma decisão precipitada dizendo "opera deit ona, tenke opera duni ... se lai - só operar, tem que operar ... se não"; os pais do bebé recém-nascido pensam e refletem, mas o médico especialista e não é bem especialista ainda com mais ou menos experiência sugere grosseiramente (é no sentido de "obrigar mesmo os pais a aceitar tal proposta) que "opera deit ona, tenke opera duni hodi salva labarik ne'e ... se lai - só operar, tem que operar mesmo para salvar o bebé ... se não". Com essa insistência do médico especialista experiente e médico não especialista menos experiente, os pais do bebé recém-nascido aceitaram tal proposta, sendo assim, após de alguns dias, o bebé conseguiu fazer "fezes"; este sinal é do ponto de vista de ciências de medicina, é devem ser reanalisadas e reestudado clinicamente no laboratório, mas esses médicos ignoram ou não ligam nada o caso onde o bebé fez "fezes", mantendo a sua decisão e fez "operação da mesma". E então, qual foi o resultado? O resultado foi catastrófico, o bebé sofreu e perdeu de vida. É um caso que acontece normalmente na vida dos casais, nomeadamente aqueles que alegremente desejavam a vinda do bebé e tristemente deixava-mo partir para o lugar onde veio. É a lei de vida que todos nós reconhecemos como "lição de vida". Contudo, voltamos ao assunto em questão "opera deit ona ... se lai - só operar ... se não", tomamos considerações de que os médicos podiam reanalisar e reestudar o caso clinicamente, para saber se manter a "operação" ou não, mas não o fizeram. Trata-se de uma atitude de egoísmo e inexperiência nas práticas medicinais sem pensar em outras alternativas chamadas "saberes locais" que podem ser úteis para a resolução do problema da medicina moderna, ou até a própria ciência moderna também tem a sua própria solução quando há interesse de cada especialista em procurar analisar e estudar mais o caso em si nas suas práticas laboratoriais; além disso, devem considerar que o parto e nascimento é um processo fisiológico e de "espiritualidade cultural" que tem suas interconexões e intercorrências, neste caso, os profissionais devem estar apto tecnicamente (quer da técnica dos saberes locais quer da técnica de saberes modernos) para oferecer uma assistência com qualidade e segura no salvamento da vida humana. 
barlaque (dote cultural) da mãe ainda não foi entregue na sua totalidade pelo pai", ou seja, "oan feto sira nia folin simu hotu ona, maibe inan nia folin, aman seidauk fó hotu - os dotes das filhas já foram recebidos, mas o dote da mãe ainda não foi entregue totalmente pelo $\mathrm{pai}^{7}$.".

É portanto, no mundo dos timorenses e outros povos que ainda vivem fortemente no universo do sagrado, cruzam-se sempre os saberes locais (usos e costumes) com saberes modernos para "salvar vidas humanas" através dos "saberes necessários", e isso é que reflete verdadeiramente a significância do termo "humanizar a vida" pela valorização da fé em crença. Neste caso, vamos considerar à água como um exemplo concreto de valorização e humanização da vida, isto é,

O toque da água torna o ambiente mais feminino, como também afirma Michel Odent, "quando você está doente, você precisa de uma mãe. E a água é um símbolo feminino, é o símbolo da mãe" e ao mesmo tempo símbolo da pureza e do amor. Neste sentido, a utilização da água no ritual de nascimento pelas mães timorenses é muito importante, porque num período de tempo pós-parto ${ }^{8}$, elas só tomam banho e consomem água quente. Acreditava-se que a religiosidade da água ajuda a tirar os coágulos e na circulação de sangue da parturiente, e ao mesmo tempo no aleitamento da criança (Araújo, 2013, p. 66).

De acordo com Irta Sequeira Baris de Araújo (2013), o processo do "sagrado parto" inicia-se com a realização do "sagrado ritual". É uma afirmação que justifica uma parte da razão epistémica do termo, mas precisamos reconhecer também que o processo do "sagrado parto" está ligada mais para a formação de uma "nova vida" espiritualmente desejada, logo, processada biologicamente. Assim, as mulheres grávidas como seres humanos que participam ativamente no processo de procriação e, após o nascimento do bebé, deixam de ser apenas espectadores e passam a ser atores principais na performance do ritual de nascimento. Desenvolvem ritos de cuidados que as auxiliam a desempenhar papéis sociais e ainda para expressar ou comunicar (de mãe, de avó, de mulher), partilhando também os símbolos e significados que têm valores e crenças comuns para a proteção e promoção de saúde do recém-nascido. Por isso, precisamos reconhecer os saberes locais como ponto de partida para a medicina moderna: - Aceitando como uma opção prioritária (para uma sociedade, por exemplo, a sociedade timorense, que ainda se associa fortemente com a relação de tridimensional cósmica - divindade celestial, espíritos dos antepassado e divindades terrenas) e, neste caso, os saberes modernos como a ciência de medicina como complemento dos saberes locais;

- Criando um diálogo entre saberes locais e modernos;

- Assegurando um ritual que beneficia o processo de realização do "parto sagrado", invocando o poder da divindade, da natureza e dos espíritos dos antepassados como uma forma de salvação de vida da mulher (a parturiente) e o "novo corpo" que vai sair no seu "sagrado ventre";

Certo é que encontramos nas mulheres uma acentuada disposição para o subjetivo, para os sentimentos, para as relações mais humanas e valores espirituais do que os homens que pensam só em "produzir", mas não cumprem os seus deveres relacionados com os valores familiares (refletindo-se, sobretudo, usos e costumes que se desencadeiam na cultura de determinadas sociedades) e não querem compreender as condições da mulher. Por isso, o homem em alguns casos (no aspeto moral e cultural) desumaniza o mundo interior da mulher que acolhe o "corpo novo", porque não sabe reconhecer o "misterioso poder" que um "sagrado ventre" tem na mulher; aliás, muitas vezes o homem não quer-saber a relação misteriosa que existe entre "mãe e filha" na conceção do "sagrado parto" e "parto sagrado". Desse modo, "a vocação de uma

\footnotetext{
${ }^{7}$ Na cultura timorense, esse é um facto consumado na relação conjugal e matrimonial estabelecida por duas famílias na dialética-relacional de fetosá-umane. Trata-se de um facto que não pode ser ignorado por qualquer timorense em torno de sua formação familiar, pois já acontece muitos casos em torno dessa prática cultural. Pelo incumprimento no pagamento dos dotes (barlaque), alguns casais já passaram de 5 e até 8 anos casados não conseguiram ter filhos devido "o dote da mãe da mulher ou do homem ainda não foi entregue pelo respetivo pai", ou devido incumprimento de algumas práticas rituais ligadas ao processo de "prenda feto foun - pedido oficial da noiva", ou devido o lugar de realização do pedido oficial de "feto foun" não apropriado (isto quer dizer que o pedido é feito na casa de umane e não na casa de algumas "feton sira - irmãs", se assim que funciona é contra a própria regra de conduta das práticas culturais existentes, ou seja, quebra o código de valorização e humanização da vida), ou devido de outras práticas rituais não-realizadas.

${ }^{8}$ Quando pensamos na alimentação da mulher estamos falando de uma dieta especial que lhe é oferecida por 40 dias, para que ela se fortaleça após o parto: milho, arroz, frango, gengibre, aibon, etc. A mulher durante estes quarenta dias deve permanecer neste quarto, podendo sair apenas para ir à casa de banho. A água ingerida deve ser quente para auxiliar na digestão e evitar a coagulação do sangue (Soares, 2010).
} 
mulher não está em função da sociedade, mas em função da humanidade, seu campo de ação não é a civilização, mas a cultura", quer dizer que a mulher é criada para dar alma ao mundo, se assim, vamos consagrar-lhe com o título "ciência de vida".

\section{Considerações Finais}

Assistimos hoje pequena proporção de propostas de humanização que atravessa o sistema de saúde e que vai da humanização do parto, dos cuidados paliativos, dos cuidados de enfermagem aos cuidados a prestar a pessoas dependentes. Sublinhando ainda Ana Raquel Matos (2011, p. 26) que estarmos perante um uso muito restrito do conceito "humanizar", já que se limita aos cuidados de saúde e respectivos profissionais. Torna-se prioritário, portanto, que a humanização alastre a outras instâncias e que se debata e promova também a necessidade de humanizar o próprio Estado, o Governo, ou seja, as instâncias de decisão e todos os que nela estão implicados. A humanização, no caso concreto, defende ainda esta investigadora que implica respeito pela mulher, pela sua vontade, mas importa não esquecer que é necessário existirem condições para que cada mulher possa fazer opções seguras nesse domínio e essas dependem, em grande medida, daqueles/as que tomam decisões sobre políticas de saúde.

Vimos que há vários vídeos internacionais sobre esta temática do parto humanizado que são irónicos ao ponto de mostrar o médico que entra na sala de partos e que nem sequer olha para a mulher que tem na cama de parto. Entra, olha para o monitor, olha para os traçados cardiotocográficos e nunca olha para a cara daquela mulher, nunca a olha nos olhos, não lhe toca. Portanto, há essa desumanização efetiva nos serviços, sem dúvida. E pensamos que todos nós podemos observar isso em qualquer área da saúde. Aliás, podemos observar também nos cuidados prestados pelas parteiras às parturientes durante o trabalho de parto, não devem ser entendidos numa só ótica do alívio da dor, mas devemos entendidos também com a ótica de observar, escutar e sentir às voz das parturientes no ato do parto. Assim, a condição essencial para que ocorra o conforto é adequar o ambiente favoravelmente à que as parturientes sejam cuidadas e sintam que estão sendo cuidadas, pois Ihes foram oferecidos o afeto, atenção e amor. Estes elementos que favorecerão o alívio, a segurança e o bem-estar das mães grávidas. Percebemos que "humanizar significa humanizar a situação do parto. A humanização do parto tem a ver com a responsabilização, devemos perceber também que os médicos são pessoas que têm as suas emoções e que os pacientes não são só pacientes. As mulheres são mulheres grávidas que precisam de apoio e atenção" (Correia, 2011, p. 28).

O diálogo é muito importante para as mães grávidas nas consultas clínicas. A consideração do diálogo do sujeito "parteira" com o sujeito "parturiente" deve ser processada a partir dos saberes tradicionais, baseados fundamentalmente nas vozes das mães grávidas como guia para interligar os laços de pensamentos e abrir espaços de comunicação na consulta médica. Aliás, o processo de diálogo neste contexto deve ser visto como fator essencial para construir uma análise crítica em todas as consultas clínicas. Mas, salienta Kleiman (1980) que não se pode falar da medicina como sistema cultural, se os enfermeiros e especialistas desta área do saber não se preocupam com todos os símbolos, instituições e padrões sociais que interferem nestas circunstâncias e que podem dar cobertura às formas de agir. De uma maneira geral, a síntese dos trabalhos de Kleiman (1988) segue, porém, uma clara orientação da exploração narrativa no âmbito de interligação entre a medicina (em particular a Psiquiatria) e a cultura, muito dela dependente de um par de conceitos apresentados no quadro do grupo de "Harvard Medical School" por Leon Eisenberg (1977), isto é, os pacientes sentem ou sofrem doença; e, enquanto os médicos diagnosticam e tratam das doenças (cf. Leal, 2009).

\section{Referências}

Araújo, I. S. B. (2013). O sagrado na cultura das parteiras do Timor-Leste. Dissertação de Mestrado, Florianópolis: Universidade Federal de Santa Catarina. Retrieved from https://repositorio.ufsc.br/bitstream/handle/123456789/ 101069/316540.pdf?sequence=1\&isAllowed $=y$

Bártolo, J. (2007). Corpo e sentido: estudos intersemióticos. Covilhã: LivrosLabcom.

Correia, R. (2011). Seminário: O parto não vigiado pela autoridade da ciência: entre o encerramento de maternidades e o parto domiciliar em Portugal. Revista e-cadernos, no 11, Coimbra: Centro de Estudos Sociais, pp. 27-231.

Draper, J. (2003). Men's passage to fatherhood: An analysis of the contemporary relevance of transition theory: Nursing Inquiry, vol. 10, no1, pp.66-78. Retrieved from http://oro.open.ac.uk/10831/3/men's_passage_to_fatherhood.pdf (acesso em 15/5/2017). 
Eisenberg, L. (1977). Disease and illness: distinctions between professional and popular ideas of sikness. Culture, Medicine and Psychiatry, no1, pp. 9-23.

Garcês, M. M. F. (2011). Vivências da figura paterna no trabalho de parto e nascimento no processo de transição para a parentalidade. Dissertação de mestrado em Enfermagem de Saúde Materna e Obstetrícia), Porto: Escola Superior de Enfermagem do Porto.

Kleinman, A. (1980). Patients and healers in the context of culture: an exploration of the borderland between Anthropology, Medicine and Psychiatry. Berkeley: University of California Press.

Kleinman, A. (1988). The illness narrative: suffering, healing and the human condition. New York: Basic Books.

Leal, J. P. F. (2009). Elementos de antropologia médica: uma abordagem antropológica sobre corpo, doença e saúde. Porto: Universidade de Fernando Pessoa.

Matos, A. R. (2011). Seminário: O parto não vigiado pela autoridade da ciência: entre o encerramento de maternidades e o parto domiciliar em Portugal. Revista e-cadernos, № 11, Coimbra: Centro de Estudos Sociais, pp. 24-26.

Paulino, V., \& Nuno, S. G. (2017). Interpretação das figuras nas portas das casas sagradas timorenses. Díli: Secretariado de Estado das Artes e Cultura da RDTL

Storti, J. (2004). O papel do acompanhante no trabalho de parto e parto: expectativas e vivências do casal. Dissertação de Mestrado, São Paulo: Escola de Enfermagem de Ribeirão Preto da Universidade São Paulo.

Soares, Dos Santos, N. (2010). Parteiras, tradição e ciências: saberes entrecruzados. Dissertação de Especialização, Díli: Universidade Nacional Timor Lorosa'e.

Woodward, K. (2000). Identidade e diferença: uma introdução teórica e conceitual. In Silva, T (org)., Identidade e diferença: a perspectiva dos estudos culturais. Petrópolis: Vozes.

\section{Sobre os Autores}

Vicente Paulino (PhD) é professor Auxiliar Convidado e Director da Unidade de Produção e Disseminação do Conhecimento do Programa de Pósgraduação e Pesquisa da Universidade Nacional Timor Lorosa'e. Licenciado e Mestre em Ciências da Comunicação pela Faculdade de Ciências Sociais e Humanas da Universidade nova de Lisboa. Doutorado em Estudos da Literatura e Cultura/especialidade em Cultura e Comunicação pela Faculdade de Letras da Universidade de Lisboa. Investigador do CEMRI-UAb - Centro de Estudos de Migração e Relações Interculturais da Universidade Aberta, Lisboa. É Membro do Conselho de Política Científica da AICSHLP - Associação Internacional de Ciências Sociais e Humanas em Língua Portuguesa (desde 2011 até 2019). É membro da direção da AIA- -SEAS - Associação Ibero Americana de Estudos do Sudeste Asiático (2013 a 2019). É membro do 'Fórum de Cadernos de Ciências Sociais' da Escolar Editora - Universidade Eduardo Mondlane de Moçambique. Tem participado e apresentado comunicações em vários eventos científicos de dimensão nacional e internacional, tendo publicado vários trabalhos académicos em livro, capítulos de livro, revista e atas de conferências.

Irta Sequeira Baris de Araújo é professora Convidada para as Disciplinas Transversais da Universidade Nacional Timor Lorosa'e desde 2014. Licenciada em Língua Portuguesa e Cultura Lusófona pela Universidade Nacional Timor Lorosa'e. Mestre em Educação e Movimentos Sociais pela Universidade Federal de Santa Catarina - Brasil. Tem publicado trabalhos sobre Timor, nomeadamente sobre cultura dos lulik (sagrado) timorense). 